\title{
Naturally Occurring R. ColBM Plasmids Belonging to the IncFIII Incompatibility Group
}

\author{
By A. SĂSĂRMAN, ${ }^{1 *}$ B. MASSIE, ${ }^{1}$ M. ZOLLINGER, ${ }^{1}$ \\ HELENE GAGNE-TELLIER, ${ }^{1}$ F. SHARECK, ${ }^{1}$ S. GARZON ${ }^{1}$ \\ AND R. MORISSET ${ }^{2}$ \\ ${ }^{1}$ Department of Microbiology and Immunology, and Department of Biochemistry, \\ University of Montreal, Montreal, Quebec, Canada H3C $3 J 7$ \\ ${ }^{2}$ Department of Microbiology, Hôpital Hôtel-Dieu, Montreal, Quebec, Canada
}

(Received 15 January 1980)

\begin{abstract}
Two Escherichia coli strains isolated from urinary tract infections were resistant to streptomycin, kanamycin, neomycin, tetracycline and sulphonamides. The strains also produced colicins $B$ and $M$. The resistance to streptomycin, kanamycin and neomycin and the ability to produce colicins $\mathrm{B}$ and $\mathrm{M}$ could be transferred to an $E$. coli $\mathrm{K} 12$ recipient. Resistance and colicinogeny markers were transferred together by conjugation, and did not segregate even after interrupted mating or phage P1-mediated transduction. Hence, the drug-resistance and colicinogeny markers were carried by the same plasmid, designated as R. ColBM plasmid. The two R. ColBM plasmids were $\mathrm{Fi}^{+}$and produced an $\mathrm{F}$-like pilus. They belonged to the IncFIII incompatibility group, being thus the first $\mathrm{R}$ plasmids identified in this group. The two plasmids were isolated and their molecular sizes were determined by electrophoresis in agarose gels and by contour length measurements. Both methods showed that both plasmids were about 52 megadaltons.
\end{abstract}

\section{INTRODUCTION}

F-like plasmids of the Enterobacteriaceae (Meynell et al., 1968) are classified into five incompatibility groups (Datta, 1975; Novick et al., 1976). A sixth group was proposed recently by Monti-Bragadin et al. (1975). The distribution of the F-like plasmids among these groups is not uniform; most of the plasmids belong to the IncFII and IncFI groups (Dennison, 1972; Hedges et al., 1973; Datta, 1975). The IncFIII, IncFIV and IncFV groups are each represented by only a few plasmids (Hedges \& Datta, 1972; Datta, 1975; De La Cruz et al., 1979). Until recently, only three plasmids were known in the IncFIII incompatibility group, namely ColBM-K98 (Frydman \& Meynell, 1969), Hly-20-72 and MIP240 (Le Minor \& Le Coueffic, 1975; Le Minor et al., 1976), and none of these carried drugresistance markers.

During a search for $\mathbf{R}$ plasmids in Escherichia coli strains isolated from urinary tract infections, several R.ColBM plasmids were identified. Incompatibility studies showed that these plasmids belonged to the IncFIII group. As they were the first R plasmids identified in this incompatibility group, the biological and molecular properties of two of them were studied extensively. The results are reported here. 


\section{METHODS}

Bacterial strains and plasmids. Bacterial strains and plasmids are listed in Table 1. Plasmids were designated as recommended by Novick et al. (1976).

Bacteriophages. Phage P1 $k c$ and the F-specific RNA phage $\mathrm{f} 2$ were obtained from $\mathrm{P}$. Fredericq.

Media. The basic medium used for the growth of bacterial strains was brain-heart infusion (BHI, Difco). Simmons citrate agar supplemented with glucose $(0.4 \%)$ and the required growth factors $\left(40 \mu \mathrm{g} \mathrm{ml}^{-1}\right.$, except for thiamin, $4 \mu \mathrm{g} \mathrm{ml}^{-1}$ ) was the synthetic medium used for genetic analysis. Media for other purposes are indicated with the corresponding techniques.

Chemicals. Chemicals were reagent grade or USP. Antibiotics were purchased from Sigma.

Antibiotic susceptibility testing. Antibiotic susceptibility of bacteria was tested by the single disk method of Kirby-Bauer (Bauer et al., 1966). The medium employed was Mueller-Hinton agar (Difco).

Colicinogeny. Colicinogeny was studied as described by Fredericq \& Smarda (1970). The group of the colicin(s) produced by bacteria was identified by use of the corresponding resistant mutants from Professor Fredericq's collection.

Haemolysin production. Haemolysin production was tested on BHI-blood agar prepared with sheep erythrocytes $(4 \%)$.

Transfer of resistance. For the transfer of resistance, $0.1 \mathrm{ml}$ of an exponential phase culture of the donor and $0.1 \mathrm{ml}$ of an overnight culture of the recipient were mixed with $5 \mathrm{ml} \mathrm{BHI}$ broth and incubated for $48 \mathrm{~h}$ at $37^{\circ} \mathrm{C}$. Simmons citrate agar containing the required growth factors $\left(40 \mu \mathrm{g} \mathrm{ml}^{-1}\right)$ and antibiotics $(25 \mu \mathrm{g}$ $\mathrm{ml}^{-1}$ ) was used for selection. When resistance was transferred from wild-type donors, the counter-selected marker was nalidixic acid sensitivity. Transconjugants were re-isolated twice on the selection medium.

Transduction. Phage P1-mediated transduction was performed as described by Lennox (1955).

Fi character. Fi character was determined as previously described (Sonea et al., 1971). Plasmids were in an Hfr host (SAS241) and the recipient strain for the transfer of chromosomal markers was W677-Azi,Sm. Selection was for $\mathrm{Thr}^{+} \mathrm{Leu}^{+}$.

Type of pilus. The type of donor pilus was determined as described by Meynell \& Datta (1966). Plasmids were in E. coli $\mathrm{C} 600$ and the second host used to obtain an HFT (high frequency of transfer; Meynell \& Datta, 1966) population was strain J53. The donor-specific phage was the RNA phage f2.

Plasmid incompatibility. For incompatibility studies, $1 \mathrm{ml}$ of an exponential phase culture of the donor and $1 \mathrm{ml}$ of an overnight culture of the recipient were mixed with $2 \mathrm{ml} \mathrm{BHI}$ broth and incubated for $1 \mathrm{~h}$ at $37^{\circ} \mathrm{C}$. In the first series of experiments, selection was made for the donor plasmid only. The transconjugants were re-isolated twice on the selection medium. This technique produced a $100 \%$ elimination of the recipient plasmid when incompatible control plasmids were used (see Table 3). In a second series of experiments, selection was made for both donor and recipient plasmid markers. To determine the stability of clones carrying both plasmids, 10 to 18 transconjugants from each transfer were subcultured ten times in antibioticfree BHI (size of the inoculum $10^{-3}$ ). The incubation period was generally short in order to reduce the probability of re-infection. At the end of the experiment at least 25 colonies per transconjugant were analysed for the presence of markers from the two plasmids.

Plasmid DNA isolation. Plasmid DNA was isolated by the method of Humphreys et al. (1975) from cleared lysates obtained by the method of Clewell \& Helinski (1969). The plasmid DNA was separated by ultracentrifugation (Beckman L2-65B preparative ultracentrifuge, Ti75 rotor, $36000 \mathrm{rev}$. $\mathrm{min}^{-1}$ for $66 \mathrm{~h}$ at $20^{\circ} \mathrm{C}$ ) in a $\mathrm{CsCl}$ density gradient (initial density $\left.1.625 \mathrm{~g} \mathrm{ml}^{-1}\right)$ in the presence of ethidium bromide $\left(500 \mu \mathrm{g} \mathrm{ml}^{-1}\right)$. DNA bands were visualized by a long-wave ultraviolet lamp. The polyallomer tubes were punctured just below the covalent closed circular DNA band and the latter was extracted with a syringe. Dialysis was performed as described by Palchaudhuri et al. (1975). DNA in the extract was precipitated by alcohol and collected by centrifugation at $10000 \mathrm{rev} . \mathrm{min}^{-1}$ in the cold. It was redissolved in Tris/EDTA buffer (10 mMTris $\mathrm{pH} 7 \cdot 9,10 \mathrm{~mm}-\mathrm{NaCl}$ and $0 \cdot 1 \mathrm{~mm}-\mathrm{Na}_{2}$ EDTA) and kept refrigerated.

Agarose gel electrophoresis. Agarose gel electrophoresis of plasmid DNA was performed as described by Meyers et al. (1976) in a vertical slab electrophoresis apparatus (model 220, Bio-Rad) at room temperature. Electrophoresis was carried out at $120 \mathrm{~V}$ and $60 \mathrm{~mA}$. Plasmids of known size were applied in the same gel as controls: R1, 62 megadaltons (Mdal); RP4, 34 Mdal; Sa, 23 Mdal; ColE1, 4.2 Mdal (Meyers et al., 1976). For the coloration of the DNA bands the gel was immersed for $30 \mathrm{~min}$ in electrophoresis buffer (Meyers et al., 1976) containing $0.5 \mu \mathrm{g}$ ethidium bromide $\mathrm{ml}^{-1}$.

Electron microscopy. Samples for electron microscopy were prepared by a modified Kleinschmidt technique (Zollinger et al., 1977). The sample contained R.ColBM plasmid DNA at $0 \cdot 2 \mu \mathrm{g} \mathrm{ml}^{-1}$, internal standard DNA (ColE1, 4.2 Mdal; Meyers et al., 1976) at $0.1 \mu \mathrm{g} \mathrm{ml}^{-1}, 0 \cdot 16 \mathrm{M}$-ammonium acetate, $0.02 \%$ cytochrome $c$ (horse heart type VI, Sigma) and sodium laurylsarcosinate (Ciba-Geigy). The sample was spread on 0.2 M-ammonium acetate. The molecules were rotary shadowed with platinum. The contour length of the plasmid molecules was determined with a Keuffel \& Esser map measurer. 


\section{Table 1. Bacterial strains and plasmids}

Designation

Hfr Cavalli
SAS241
J53
C600
W677-Azi,Sm

AB2463

$185 \mathrm{Nx}$

186/T1

$185 / \mathrm{Ab} 3 \mathrm{a}$

$185 / \mathrm{Ab} 3 \mathrm{a} / \mathrm{T} 1$

J53/R1

SAS313

L-A633

SAS393

SLM

SAS407

SAS408

SAS409

SAS410

SAS413

SAS414

SAS417

SAS418

SAS419

R1

RP4

$\mathrm{Sa}$

ColE1

MIP240

pSAS1201

pSAS1203

pSAS1205
Genotype

Derivatives of Escherichia coli $\mathrm{K} 12$

met $B 1$ rel-1, Hfr POA2

Hfr Cavalli nal

pro- 22 met- $63, \mathrm{~F}^{-}$

thr-1 leu-6 thi-1 lac Y1 tonA21 supE44 $\lambda^{-}, \mathrm{F}^{-}$

thr-1 leu-6 thi-1 lac Y1 xyl-7 ara-13 mtl-2 gal-3 ton $A 2 \lambda^{\mathrm{R}}$ azi $r p s L$ sup E44, $\mathrm{F}^{-}$

thr-1 leu-6 thi-1 argE3 his-4 proA2 mtl-1 xyl-5 ara-15 galK2 lac Y1 tsx-33 rpsL31 sup-37 $\operatorname{rec} A 13 \lambda^{-}, \mathrm{F}^{-}$

prototroph, colicin-sensitive

185 resistant to colicin $\mathrm{M}$

185 resistant to colicin $B$

185 resistant to colicins $B$ and $M$

$\mathrm{R} 1$ in $\mathrm{J} 53$

$\mathrm{R} 1$ in $\mathrm{C} 600$

thr leu thi, ColE1+, $\mathrm{F}^{-}$

$\mathrm{R} 1, \mathrm{RP} 4$ and $\mathrm{Sa}$ in L-A633

MIP240 in C600, nal rpsL

pSAS1205 in SAS241

pSAS1205 in C600

pSAS1201 in SAS241

pSAS1201 in C600

pSAS1203 in SAS241

pSAS1203 in C600

pSAS1205 in AB2463

pSAS1201 in AB2463

pSAS1203 in AB2463

\section{Plasmids}

amp cml str kan sul, $\mathrm{Fi}^{+}$, IncFII

amp tet kan

str cml kan sul

ColE1-K30

$\mathrm{Hly}^{+}, \mathrm{Fi}^{+}$, IncFIII

str kan neo, $\mathrm{ColB}^{+}, \mathrm{ColM}^{+}, \mathrm{Fi}^{+}$, IncFIll

str kan neo, $\mathrm{ColB}^{+}, \mathrm{ColM}^{+} \mathrm{Fi}^{+}$, IncFIII

tet, $\mathrm{Fi}^{+}$, IncFII
Source

W. Hayes

This laboratory

N. Datta

F. Jacob

F. Jacob

B. Bachmann

(CGSC)

P. Fredericq

P. Frederica

P. Fredericq

P. Fredericq

N. Datta

This laboratory

S. Luria

This laboratory

L. Le Minor

This laboratory

This laboratory

This laboratory

This laboratory

This laboratory

This laboratory

This laboratory

This laboratory

This laboratory

N. Datta

N. Datta

N. Datta

S. Luria

L. Le Minor

This laboratory

This laboratory

This laboratory

\section{RESULTS}

Transferability by conjugation. The original plasmid-carrying $E$. coli strains were isolated from urinary tract infections. They were resistant to streptomycin $(\mathrm{Sm})$, kanamycin $(\mathrm{Km})$, neomycin $(\mathrm{Nm})$, tetracycline $(\mathrm{Tc})$ and sulphonamides $(\mathrm{Su})$ and produced a B-type colicin. The resistance to $\mathrm{Sm}, \mathrm{Km}$ and $\mathrm{Nm}$, as well as the ability to produce the colicin, could be transferred to derivatives of $E$. coli K12 (SAS241 and C600) by conjugation. Resistance and colicinogeny markers were always transferred together, even after interrupted mating or P1-mediated transduction (results not shown).

Identification of the colicin. Preliminary identification of the colicin produced by the plasmid-carrying strains was based on the results obtained with a colicin B-resistant mutant. The zone of inhibition obtained with this mutant was barely visible compared with the medium-sized zone obtained with the colicin-sensitive indicator strains. Suspecting the presence of a colicin $\mathrm{M}$, which often accompanies colicin B production (Fredericq \& Smarda, 1970), a double mutant, resistant to colicins B and M (185/Ab 3a/T1), was used. As expected, the double mutant was totally insensitive to the colicins produced by the two plasmids. Hence, the two R plasmids carry determinants for colicinogeny B and M. They will be designated collectively as $\mathbf{R}$. ColBM plasmids.

Fi character. The Fi character of the two plasmids was determined in an Hfr donor (SAS241). Both plasmids inhibited the transfer of chromosomal markers to an $\mathrm{F}^{-}$recipient 
Table 2. Increase in plaque-forming units of phage $f 2$ in the presence of various plasmid-carrying strains

\begin{tabular}{|c|c|c|c|c|c|}
\hline \multirow[b]{2}{*}{ Strain } & \multirow[b]{2}{*}{ Plasmid } & \multicolumn{3}{|c|}{ Plaque-forming units $\mathrm{ml}^{-1}$} & \multirow[b]{2}{*}{$\begin{array}{c}\text { Increment } \\
\left(T_{1} / T_{0}\right)\end{array}$} \\
\hline & & $\begin{array}{c}\text { Second } \\
\text { host* }\end{array}$ & $\begin{array}{c}\text { Initial } \\
\left(T_{0}\right)\end{array}$ & $\begin{array}{l}\text { After } 1.5 \text { to } 2 \mathrm{~h} \\
\text { incubation } \\
\left(T_{1}\right)\end{array}$ & \\
\hline $\begin{array}{l}\text { SAS410 } \\
\text { SAS410 }\end{array}$ & $\begin{array}{l}\text { pSAS1201 } \\
\text { pSAS1201 }\end{array}$ & $\overline{\mathrm{J} 53}$ & $\begin{array}{l}1.3 \times 10^{4} \\
2.6 \times 10^{4}\end{array}$ & $\begin{array}{l}4.9 \times 10^{6} \\
6.0 \times 10^{8}\end{array}$ & $\begin{array}{r}377 \\
23077\end{array}$ \\
\hline $\begin{array}{l}\text { SAS414 } \\
\text { SAS414 }\end{array}$ & $\begin{array}{l}\text { pSAS1203 } \\
\text { pSAS1203 }\end{array}$ & $\overline{\mathrm{J} 53}$ & $\begin{array}{l}2 \cdot 1 \times 10^{4} \\
5 \cdot 2 \times 10^{4}\end{array}$ & $\begin{array}{l}2.5 \times 10^{7} \\
1.8 \times 10^{9}\end{array}$ & $\begin{array}{r}1190 \\
34615\end{array}$ \\
\hline $\begin{array}{l}\text { Hfr Cavalli } \\
\text { C600 } \\
\text { J53 }\end{array}$ & F (integrated) & - & $\begin{array}{l}4.4 \times 10^{6} \\
1.4 \times 10^{3} \\
9.3 \times 10^{3}\end{array}$ & $\begin{array}{l}1.5 \times 10^{11} \\
7.0 \times 10^{2} \\
9.0 \times 10^{3}\end{array}$ & $\begin{array}{c}34091 \\
-\end{array}$ \\
\hline
\end{tabular}

* Used in the case of an HFT population. The plasmid-carrying strain and strain J53 were inoculated in TYECa (Oxoid Tryptone, $10 \mathrm{~g} \mathrm{l}^{-1}$; yeast extract, $1 \mathrm{~g}^{-1} ; \mathrm{NaCl}, 8 \mathrm{~g} \mathrm{l}^{-1}$; glucose, $0 \cdot 15 \%$; $\mathrm{CaCl}_{2}, 2 \mathrm{~mm}$ ) and incubated overnight. The following day the culture was diluted $1 / 20$ in the same medium and re-incubated for $2 \mathrm{~h}$ at $37^{\circ} \mathrm{C}$. Bacteria were then infected with phage f2 (multiplicity of infection, about 20) and further incubated for a short period to allow phage adsorption. Excess phage was neutralized with $f 2$ antiserum and the mixture was filtered (Millipore membrane, $0.45 \mu \mathrm{m}$ pore size). The filter was transferred to TYECa and incubated for 1.5 to $2 \mathrm{~h}$ at $37^{\circ} \mathrm{C}$. The phage titre was determined in samples taken at the beginning $\left(T_{0}\right)$ and at the end $\left(T_{1}\right)$ of the incubation period. The increment $(I)$ of the phage titre is given by the formula $I=T_{1} / T_{0}$. When $I$ was determined in a non-HFT population the same method was used except that the second host (strain J53) was omitted.

\section{Table 3. Incompatibility reactions of $\mathrm{R}$. ColBM plasmids}

$\begin{array}{llllccc}\text { Donor } & \text { Plasmid in donor } & \text { Recipient } & \text { Plasmid in recipient } & \begin{array}{c}\text { No. of } \\ \text { Selected } \\ \text { marker* }\end{array} & \begin{array}{c}\text { trans- } \\ \text { conjugants } \\ \text { analysed }\end{array} & \begin{array}{c}\text { Elimination } \\ \text { of recipient } \\ \text { plasmid (\%) }\end{array} \\ \text { SAS409 } & \text { pSAS1201 } & \text { SLM } & \text { MIP240 (IncFIII) } & \text { Km } & 100 & 100 \\ \text { SAS413 } & \text { pSAS1203 } & \text { SLM } & \text { MIP240 (IncFIII) } & \text { Km } & 100 & 100 \\ \text { SAS409 } & \text { pSAS1201 } & \text { SAS408 } & \text { pSAS1205 (IncFII) } & \text { Km } & 100 & 25 \\ \text { SAS407 } & \text { pSAS1205 (IncFII) } & \text { SAS410 } & \text { pSAS1201 } & \text { Tc } & 140 & 17 \cdot 8 \\ \text { SAS413 } & \text { pSAS1203 } & \text { SAS408 } & \text { pSAS1205 (IncFII) } & \text { Km } & 100 & 23 \\ \text { SAS407 } & \text { pSAS1205 (IncFII) } & \text { SAS414 } & \text { pSAS1203 } & \text { Tc } & 140 & 14 \cdot 2 \\ \text { SAS407 } & \text { pSAS1205 (IncFII) } & \text { SAS313 } & \text { R1 (IncFII) } & \text { Tc } & 100 & 100 \\ \text { SAS407 } & \text { pSAS1205 (IncFII) } & \text { SLM } & \text { MIP240 } & \text { Tc } & 128 & 2 \cdot 3\end{array}$

* In this series of experiments selection was made for the donor plasmid only. Transconjugants were reisolated twice on the selection medium.

Table 4. Effect of the recA mutation of the host on partial incompatibility

$\begin{array}{llllccc}\text { Donor } & \text { Plasmid in donor } & \begin{array}{c}\text { recA } \\ \text { recipient }\end{array} & \text { Plasmid in recipient } & \begin{array}{c}\text { Selected } \\ \text { marker* }\end{array} & \begin{array}{c}\text { No. of } \\ \text { trans- } \\ \text { conjugants } \\ \text { analysed }\end{array} & \begin{array}{c}\text { Elimination } \\ \text { of recipient } \\ \text { plasmid (\%) }\end{array} \\ \text { SAS409 } & \text { pSAS1201 } & \text { SAS417 } & \text { pSAS1205 (IncFII) } & \text { Km } & 200 & 74.5 \\ \text { SAS407 } & \text { pSAS1205 (IncFII) } & \text { SAS418 } & \text { pSAS1201 } & \text { Tc } & 100 & 2 \\ \text { SAS413 } & \text { pSAS1203 } & \text { SAS417 } & \text { pSAS1205 (IncFII) } & \text { Km } & 100 & 5 \\ \text { SAS407 } & \text { pSAS1205 (IncFII) } & \text { SAS419 } & \text { pSAS1203 } & \text { Tc } & 100 & 3 \\ \text { J53/R1 } & \text { R1 (IncFII) } & \text { SAS417 } & \text { pSAS1205 (IncFII) } & \text { Km } & 100 & 65 \dagger\end{array}$

* In this series of experiments selection was made for the donor plasmid only. Transconjugants were reisolated twice on the selection medium.

$\dagger$ After repeated inoculations of the remaining 35 transconjugants in antibiotic-free medium (ten subcultures in BHI at short intervals; size of the inoculum $10^{-3}$ ), only $23.4 \%$ of the resulting colonies still carried both plasmids. 

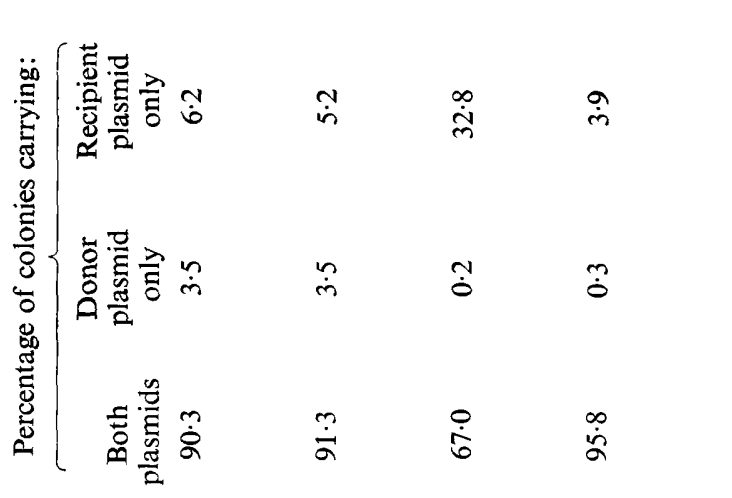

害

密这

更

옽

递

可

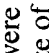

3.

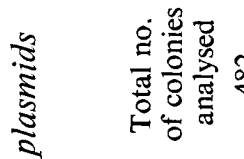

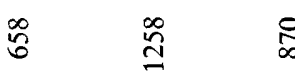

空

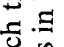

बू

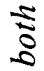

苞

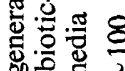

$\frac{8}{2}$

$\frac{8}{2} \quad \frac{8}{2}$

范范

空

额

$\dot{\mathrm{z}}: \equiv$

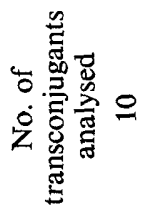

$\stackrel{+}{-1}$

$\stackrel{\infty}{\sim}$

$\simeq$

.

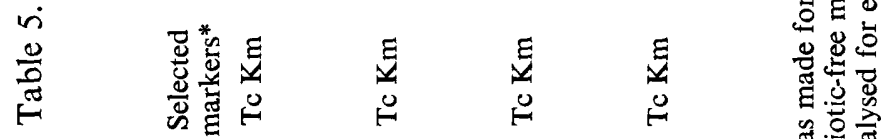

율 율

동 동

政

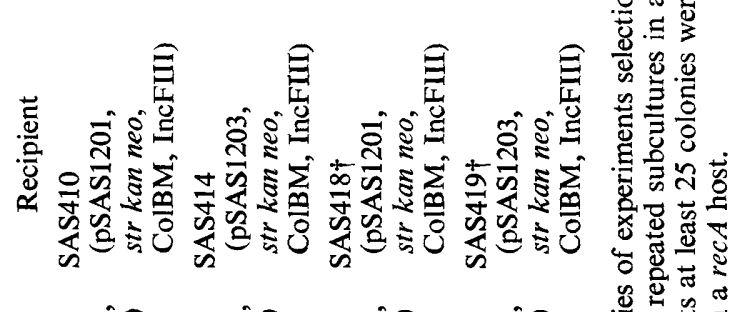

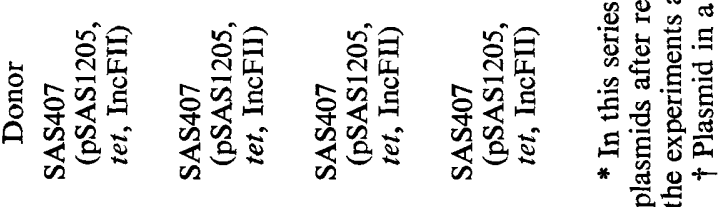


(W677). Hence they are $\mathrm{Fi}^{+}$plasmids like the majority of $\mathrm{R}$ plasmids isolated from $E$. coli (Meynell et al., 1968).

Pilus production. The results obtained in studies on the type of pilus produced are presented in Table 2. The production of an F-type pilus by the two R.ColBM plasmids is clearly shown by the net increase in plaque-forming units, particularly when HFT populations were used. Hence, the two plasmids are F-like plasmids, as defined by Meynell et al. (1968).

Incompatibility studies. The results of the incompatibility studies with R.ColBM plasmids are presented in Table 3. The 100\% elimination of the MIP240 (IncFIII) plasmid by the R.ColBM plasmids clearly indicates that the latter belong to the IncFIII incompatibility group.

The results obtained with an IncFII plasmid are more difficult to interpret (Table 3) since both R.ColBM plasmids give a partial incompatibility reaction with pSAS1205 (IncFII). This partial incompatibility is not due to a delayed elimination of one of the plasmids, since even after ten subcultures in antibiotic-free medium more than $90 \%$ of the clones originally selected for the presence of the two plasmids were still carrying both of them (Table 5, lines 1 and 2).

The study of the partial incompatibility between R. ColBM and IncFII plasmids in a rec $A$ host (Table 4) allows easy differentiation between the two R. ColBM plasmids (pSAS 1201 and pSAS1203). In the case of the former, $74.5 \%$ of the transconjugants lost the IncFII plasmid when selection was made for pSAS1201, whereas the reciprocal cross gave only $2 \%$ elimination of pSAS1201 (Table 4). This asymmetrical loss of the IncFII plasmid was also evident when $r e c A$ transconjugants carrying both plasmids were subcultured in an antibiotic-free medium (Table 5, line 3).

In the case of plasmid pSAS1203, partial incompatibility between pSAS1203 and the IncFII plasmid (pSAS1205) in a rec $A$ host was diminished in both directions (Table 4, lines 3 and 4) when selection was made for the donor plasmid. However, when transconjugants carrying both plasmids were subcultured in antibiotic-free medium, an asymmetric loss of pSAS1205 was obtained as with pSAS1201 (Table 5, line 4). Nonetheless, the elimination of IncFII by pSAS1203 was only $3.9 \%$, whereas the elimination of the same plasmid by pSAS1201 was $32 \cdot 8 \%$ (Table 5 , lines 3 and 4 ).

Molecular studies. The molecular size of the two R.ColBM plasmids was determined by agarose gel electrophoresis and by contour length measurements in the electron microscope. The agarose gel electrophoresis results indicated that both R.ColBM plasmids were about 51 Mdal. Contour length measurements of ten molecules of each R.ColBM plasmid, using plasmid ColE1 as internal standard (Fig. 1), showed that both were about $52 \mathrm{Mdal}$.

\section{DISCUSSION}

There are only a few reports of naturally occurring plasmids which carry resistance and colicinogenic markers on the same molecule (Siccardi, 1966; Fredericq \& Delhalle, 1972; Chabbert et al., 1972) and I-like R-plasmids probably represent the exception to the rule (Falkow, 1975). This is puzzling since the association of the two types of markers might offer a selective advantage to the host. Moreover, it is difficult to understand how Col plasmids can avoid 'contamination' with resistance genes, especially with those carried by transposons (Cohen \& Kopecko, 1976; Starlinger \& Saedler, 1976). The same observation is also true for Ent plasmids which only rarely carry resistance genes (Gyles et al., 1977). It would therefore seem that recombination between different types of plasmids is less frequent in nature than in laboratory conditions (Fredericq \& Delhalle, 1972).

Study of the incompatibility of the R.ColBM plasmids showed that they belong to the IncFIII incompatibility group. Plasmids belonging to this group were found to give partial incompatibility reactions either with IncFII plasmids (Finnegan \& Willetts, 1972; this paper) 


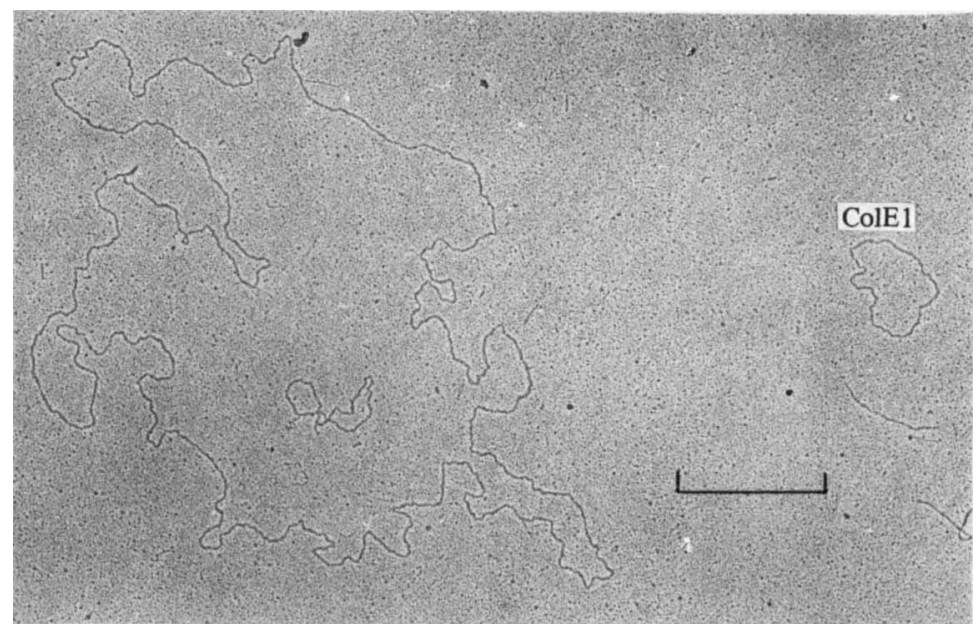

Fig. 1. Electron micrograph of pSAS1201 (R.ColBM) and ColE1 plasmids. Bar marker represents $1 \mu \mathrm{m}$.

or with an IncFIV plasmid (Le Minor \& Le Coueffic, 1975; De La Cruz et al., 1979). However, these partial reactions cannot be compared to the strong incompatibility reactions between IncFIII plasmids as observed in the present study (see Table 3). Therefore, we consider that IncFIII should be maintained as an independent group rather than as a member of an IncFIII-IncFIV incompatibility complex (De La Cruz et al., 1979), at least until cloning experiments (Cabello et al., 1976; Timmis et al., 1978; Manis \& Kline, 1978) clearly establish the nature of its incompatibility relations.

The mechanism of partial incompatibility is not well understood and the repressor model of incompatibility (Pritchard et al., 1969; Novick, 1969; Uhlin \& Nordström, 1975; Cabello et al., 1976; Timmis et al., 1978) allows several different interpretations of this phenomenon. Firstly, partial incompatibility might reflect the presence of a less specific effector of incompatibility (i.e. repressor) which reacts with plasmids of different specificities. This also supposes that the operator of an IncFIII plasmid might be recognized by repressors of various specificities. We do not have experimental evidence which could favour such a mechanism.

A second hypothesis may consider partial incompatibility as a particular form of a double incompatibility (Grant \& Pittard, 1974; Cabello et al., 1976; Timmis et al., 1978) with one of the repressors being partially defective. The partial defectiveness of one of the repressors could be the direct result of the recombination which originated the composite plasmid. If this hypothesis is correct, and if the conditions which protect lambda repressor from inactivation, such as a recA mutation (Roberts \& Roberts, 1975; Roberts et al., 1978), could also protect a partial defective incompatibility repressor, we should observe the appearance of an asymmetrical loss of one of the plasmids in a $\operatorname{rec} A$ host. This is because protection of a partially defective repressor might re-establish the conditions of a double incompatibility, characterized by the asymmetrical loss of one of the plasmids (Cabello et al., 1976; Timmis et al., 1978). Such an asymmetrical loss was indeed observed when incompatibility between R. ColBM and IncFII plasmids was studied in a rec $A$ host (see Tables 4 and 5). This would suggest that partial incompatibility of R.ColBM and IncFII plasmids might be due to the production of a defective IncFII incompatibility repressor by the R. ColBM plasmids. However, we must be cautious with this interpretation until the protective effect of a recA mutation on incompatibility repressors is clearly established.

Other interpretations of the partial incompatibility are also possible, such as a divergent evolution of two identical incompatibility determinants (Manis \& Kline, 1978). Finally, it might be possible that several different mechanisms can lead to a partial incompatibility and only cloning experiments will establish the real mechanism in each case. 
The two R. ColBM plasmids isolated in the present study are the first $\mathrm{R}$ plasmids belonging to the IncFIII incompatibility group described so far. The uniqueness of the R.ColBM plasmids makes them ideal epidemiological markers for studying the spread of drugresistant strains in a hospital environment. It is known that the appearance of a drugresistant strain in a patient is more often the result of the spread of hospital strains rather than of an in vivo transfer of an R plasmid (Richmond, 1975; Richmond \& Petrocheilou, 1978). Such a mechanism seems also to be confirmed in the present case, since $E$. coli strains carrying R.ColBM plasmids were isolated from two other patients in the same hospital (unpublished results).

The isolation of the first IncFIII plasmids carrying resistance genes is also important for incompatibility studies. The other known plasmids in this group (Frydman \& Meynell, 1969; Le Minor \& Le Coueffic, 1975; Le Minor et al., 1976) cannot be selected for easily and can be used mainly as recipient plasmids. This makes the study of incompatibility difficult, particularly with other plasmids that also cannot be selected for. The newly isolated R. ColBM IncFIII plasmids do not have this disadvantage and can be used in incompatibility studies as either donor or recipient plasmids.

We are indebted to Claude Vézina and Talat El Kersh for helping us with their experience in plasmid isolation. The contribution of Michel Truffy and Pierre Saint-Michel is gratefully acknowledged. Part of this investigation was supported by grant MA4997 from the Medical Research Council of Canada and by grant CAFIR 113 from the University of Montreal to A.S. B. M. is a recipient of a studentship from the Medical Research Council of Canada.

\section{REFERENCES}

Bauer, A. W., Kirby, W. M. M., Sherris, J. C. \& TURCK, M. (1966). Antibiotic susceptibility testing by a standardized single disk method. American Journal of Clinical Pathology 45, 493-496.

Cabello, F., Timmis, K. \& Cohen, S. N. (1976). Replication control in a composite plasmid constructed by in vitro linkage of two distinct replicons. Nature, London 259, 285-290.

Chabbert, Y. A., Scavizzi, M. R., Witchitz, J. L., Gerbaud, G. R. \& Bouanchaud, D. H. (1972). Incompatibility groups and the classification of $\mathrm{fi}^{-}$resistance factors. Journal of Bacteriology 112, 666-675.

Clewell, D. B. \& Helinski, D. R. (1969). Supercoiled circular DNA-protein complex in Escherichia coli: purification and induced conversion to an open circular DNA form. Proceedings of the National Academy of Sciences of the United States of America 62, 1159-1166.

Cohen, S. N. \& Kopecko, D. J. (1976). Structural evolution of bacterial plasmids: role of translocating genetic elements and DNA sequence insertions. Federation Proceedings 35, 20312036.

DatTa, N. (1975). Epidemiology and classification of plasmids. In Microbiology 1974, pp. 9-15. Edited by D. Schlessinger. Washington, D.C.: American Society for Microbiology.

De La Cruz, F., Zabala, J. C. \& Ortiz, J. M. (1979). Incompatibility among $\alpha$-hemolytic plasmids studied after inactivation of the $\alpha$-hemolysin gene by transposition of TN802. Plasmid 2, 507519.

DENNISON, S. (1972). Naturally occurring R factor, derepressed for pilus syntheses, belonging to the same compatibility group as the sex factor $F$ of E. coli K12. Journal of Bacteriology 109, 416-422.

Falkow, S. (1975). Infectious Multiple Drugresistance. London: Pion Ltd.

Finnegan, D. \& Willetts, N. (1972). The nature of the transfer inhibitor of several F-like plasmids. Molecular and General Genetics 119, 57-66.

FredericQ, P. \& Delhalle, D. (1972). Recombinaison entre facteurs $R$ et facteurs colicinogènes chez Escherichia coli K12. I. Production des recombinants. Annales de l'Institut Pasteur 122, 909-921.

FredericQ, P. \& Smarda, J. (1970). Complexité du facteur colicinogène B. Annales de l'Institut Pasteur 118, 767-774.

Frydman, A. \& Meynell, E. (1969). Interactions between derepressed F-like $\mathbf{R}$ factors and wild type colicin B factors: superinfection immunity and repressor susceptibility. Genetical Research 14, 315-332.

Grant, A. J. \& PitTARD, J. (1974). Incompatibility reactions of $\mathrm{R}$ plasmids isolated from $E$. coli of animal origin. Journal of Bacteriology 120, 185190.

Gyles, C. L., Palchaudhuri, S. \& Maas, W. K. (1977). Naturally occurring plasmid carrying genes for enterotoxin production and drug resistance. Science 198, 198- 199.

Hedges, R. W. \& Datta, N. (1972). R124, an $f^{+}$R factor of a new compatibility class. Journal of General Microbiology 71, 403-405.

Hedges, R. W., Datta, N., Coetzee, J. N. \& Dennison, S. (1973). R factors from Proteus morganii. Journal of General Microbiology 77, 249-259. 
Humphreys, G. O., Willshaw, G. A. \& Anderson, E. S. (1975). A simple method for the preparation of large quantities of pure plasmid DNA. Biochimica et biophysica acta 383, 457-463.

Le Minor, S. \& Le Couefric, E. (1975). Etude sur les hémolysines des Enterobacteriaceae. Annales de Microbiologie (Institut Pasteur) 126B, 313-332.

le Minor, L., Coynault, C., Chabbert, U., Gerbaud, G. \& Le Minor, S. (1976). Groupes de compatibilité de plasmides métaboliques. Annales de Microbiologie (Institut Pasteur) 127B, 31- 40.

LENNOX, E. S. (1955). Transduction of linked genetic characters of the host by bacteriophage $\mathrm{P} 1$. Virology 1, 190-206.

Manis, J. J. \& Kline, B. C. (1978). F-plasmid incompatibility and copy number gene: their map locations and interactions. Plasmid 1, 492-507.

Meyers, J. A., Sanchez, D., Elwell, L. P. \& Falkow, S. (1976). Simple agarose gel electrophoretic method for the identification and characterization of plasmid deoxyribonucleic acid. Journal of Bacteriology 127, 1529-1537.

Meynell, E. \& DatTA, N. (1966). The relation of resistance transfer factors to the $\mathrm{F}$-factor (sexfactor) of Escherichia coli K12. Genetical Research 7, 134-140.

Meynell, E., Meynell, G. G. \& Datta, N. (1968). Phylogenetic relationships of drug-resistance factors and other transmissible bacterial plasmids. Bacteriological Reviews 32, 55-83

Monti-Bragadin, C., Samer, L., Rottini, G. D. \& PANI, B. (1975). The compatibility of Hly factor, a transmissible element which controls $\alpha$-haemolysin production in Escherichia coli. Journal of General Microbiology 86, 367-369.

Novick, R. P. (1969). Extrachromosomal inheritance in bacteria. Bacteriological Reviews 33, 210 263.

Novick, R. P., Clowes, R. C., Cohen, S. N., Curtiss, R. III, Datta, N. \& Falkow, S. (1976). Uniform nomenclature for bacterial plasmids: a proposal. Bacteriological Reviews 40, 168-189.

Palchaudhuri, S., Bell, E. \& Salton, M. R. (1975). Electron microscopy of plasmid DNA from Neisseria gonorrhoeae. Infection and Immunity 11, 1141-1146.
Pritchard, R. H., Barth, P. T. \& Collins, J. (1969). Control of DNA synthesis in bacteria. Symposia of the Society for General Microbiology 19, 263-297.

RichmoND, M. H. (1975). R factors in man and his environment. In Microbiology-1974, pp. 27-35. Edited by D. Schlessinger. Washington, D.C.: American Society for Microbiology.

Richmond, M. H. \& Petrocheilou, V. (1978). Rfactor transfer in vivo in humans. In Microbiology1978, pp. 273-276. Edited by D. Schlessinger. Washington, D. C.: American Society for Microbiology.

Roberts, J. W. \& Roberts, C. W. (1975). Proteolytic cleavage of bacteriophage lambda repressor in induction. Proceedings of the National Academy of Sciences of the United States of America 72, 147-151.

Roberts, J. W., Roberts, C. W. \& Craig, N. L. (1978). Escherichia coli recA gene product inactivates phage $\lambda$ repressor. Proceedings of the National Academy of Sciences of the United States of America 75, 4714-4718.

SicCARDI, A. G. (1966). Colicin resistance associated with resistance factors in Escherichia coli. Genetical Research 8, 219-228.

Sonea, S., Săsărman, A., Surdeanu, M. \& Martineau, B. (1971). Ségrégation indépendante des propriétés restrictives des facteurs $\mathrm{R}$ isolés au Canada en 1956-1957. Canadian Journal of Microbiology 17, 813-817.

StARlinger, P. \& SAEDler, H. (1976). IS-elements in microorganisms. Current Topics in Microbiology and Immunology 75, 111-152.

Timmis, K. N., Andres, I. \& Slocombe, P. M. (1978). Plasmid incompatibility: cloning analysis of an inc FII determinant of R6-5. Nature, London 273, 27-32.

Uhlin, B. E. \& Nordström, K. (1975). Plasmid incompatibility and control of replication: copy mutants of the R-factor R1 in Escherichia coli K-12. Journal of Bacteriology 124, 641-649.

Zollinger, M., Guertin, M. \& Mamet-Bratley, M. D. (1977). A new electron microscopic method for studying protein-nucleic acid interactions. Analytical Biochemistry 82, 196-203. 